\title{
Birds of Madge Lake
}

Introduction: The summer meeting of the Saskatchewan Natural History Society will be held this year at Madge Lake in the Duck Mountain Provincial Park. In its two-day programme of field trips, the Society will be studying an area in which serious field work has already been done, notably by parties from the Provincial Museum of Natural History who visited Madge Lake in 1926 (from May 6 to June 19) and again in 1951 (from May 15 to June 22 ). It should be interesting to compare the records of observations which will be made by members of the society at the summer meeting in 1956 with the list of birds established for the area by the Museum camp in 1926 and 1951.

The Area. Madge Lake lies 150 miles north-east of Regina, about two miles from the Manitoba border, in the well-wooded hills of the Duck Mountain Reserve. Although Madge Lake is not actually in the Canadian Zone, since it lies geographically somewhat south of it, its plant and animal life is typical of the Canadian Zone. The characteristic Canadian Zone flora and fauna plus the influx of Transition Zone species make it one of the most interesting spots in the province. In the report of the Provincial Naturalist for the year ending April 30, 1927, H. H. Mitchell describes the following characteristic features of the area-dense underbrush among the thick stands of poplar, spruce and birch; masses of huge ferns growing to a height of from four to five feet, with other species that include the so-called Maiden-hair fern well known in Ontario; the orchid known as the Lady's Slipper; marmot, deer, red squirrels, and a bear that appeared one day at camp.

\section{Characteristic Birds of the Area Noted by the Museum Party May 6-June 19, 1926}

Readers of Taverner's Birds of Canada will remember the following species that Taverner lists as especially typical of the Canadian life zone: Brown-capped $\mathrm{Ch}$ i ck a d $\epsilon$ e, Olive-backed Thrush, Hermit Thrush, Three-toed Woodpecker, Canada Jay, White-throated Spar- row, Junco. Mitchell's comment on what he found most striking in the bird life of the district supplement Taverner's list. "The surprising number of Crested Flycatchers seen," he repcrted, "indicated it a common species, though sa scarce elsewhere in the province. Warblers were well represented and among these was found another surprise in the numbers of Blackburnian Warblers seen, probably the most brilliant of this family of tiny, bright-coloured woodland birds. Specimens secured of Blackburnian Warbler, Connecticut Warbler and Philadelphia Vireo are all new to the museum collection of mounted birds, as was also the Ringnecked Duck, scarce elsewhere in the province but common here. The American Golden-eye was the common duck of the lake,but the Ringnecked seemed to prefer the numerous sloughs or small lakes scattered over the district, especially those bodies of water where water lilies grew, indicating, one would suppose, purer water (less alkaline) than others . . Pelicans were for some reason absent, with a scarcity of Cormorants equally inexplicable, as the lake is well stocked with fish, pike for the most part, but also fine pickerel. Common Loons were very numerous, unusually tame and always interesting with their evident sense of curiosity and weird notes and calls which they kept up day and night. Several nests of this diver were found, each with its handsome, dark coloured eggs. Two sets taken for specimens were replaced within a few days in each case; very few other birds will lay a second time in a nest robbed or disturbed, which is usually deserted and a new one built. Vultures, with their grand soaring flight, were always to be seen, also in unusual numbers. The presence of Canada Jays, Pileated Woodpecker, Hudsonian Chickadee and Swamp Sparrow all breeding there would indicate a northern influence besides the eastern; before mentioned." A list of the birds positively identified by Mitchell and the Museum staff in the district was published in the Kamsack Times, June 18,1926 , to stimulate a local interest in natural history. 


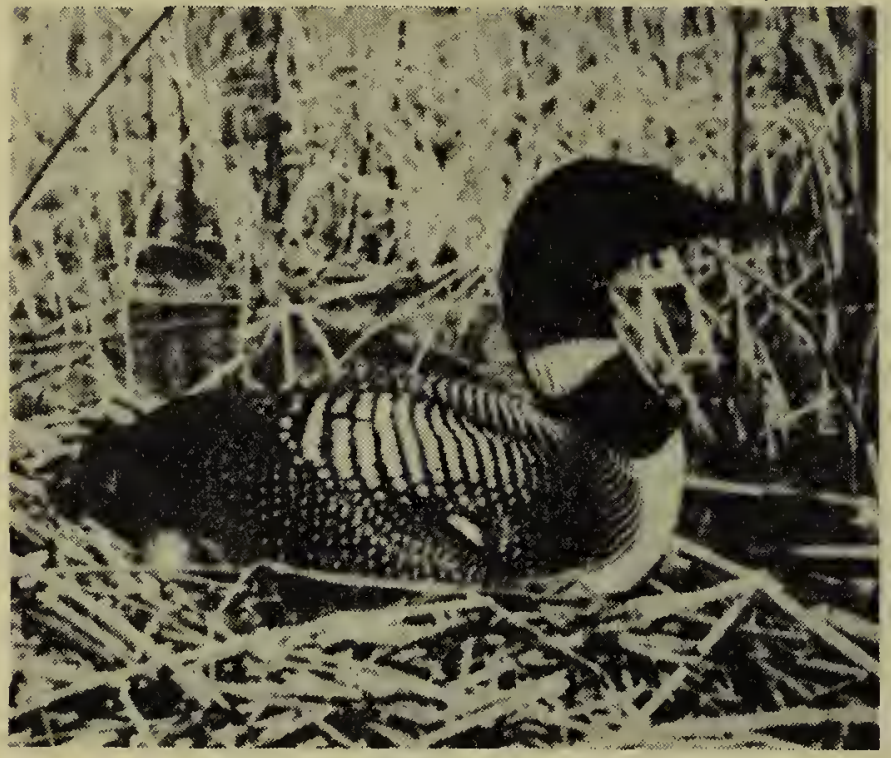

Loon

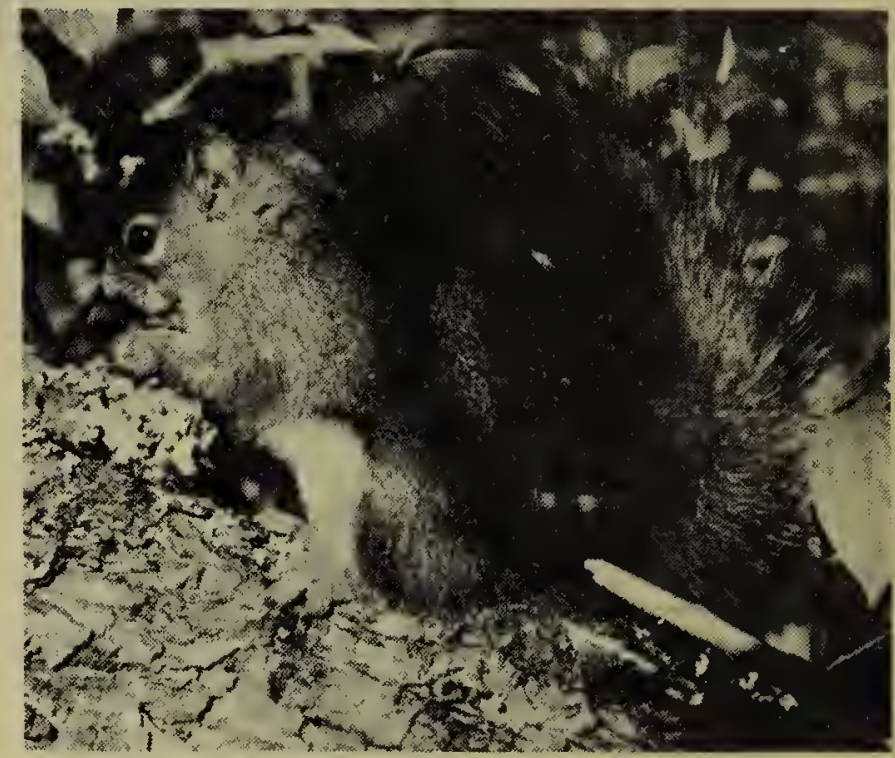

Red Squirrel

\section{LIST OF BIRDS RECORDED AT MADGE LAKE BY THE MUSEUM PARTY}

MAY 15 - JUNE 22, 1951

The 1951 Museum Camp arrived at Madge Lake May 15 with F. G. Bard, F. W. Lahrman and A. E. Swanston in the party. The sky was overcast, the weather was cold, and it was snowing lightly. The trees were just beginning to turn green. Birds recorded: Common Loon, Holboell's Grebe, Western Grebe, Pied-billed Grebe (Pelican), Great Blue Heron, Bittern, Canada Goose - captive), Mallard, Black Duck, Baldpate, Green-winged Teal, Blue-winged Teal, Ring-necked Duck, Canvasback, Lesser Scaup, American Golden-eye, Buffle-head, White-winged Scoter, American Merganser, Red-breasted Merganser, Turkey Vulture, Goshawk, Sharp-shinned Hawk, Cooper's Hawk, Red-tailed Hawk, Swainson's Hawk, Marsh Hawk, Bald Eagle, Osprey, Sparrow Hawk, Ruffed Grouse, Ring-necked Pheasant (introduced), Virginia Rail, Sora Rail, Coot, Killdeer (Lesser Yellow-legs), Spotted Sandpiper (Ring-billed Gull), (Franklin's Gull), (Bonaparte's Gull), Common Tern, Black Tern, Mourning Dove, Horned Owl, Nighthawk, Ruby-thrơated Hummingbird, Belted Kingfisher, Yellow-shafted Flicker, Yellow-bellied Sapsucker, Pileated Woodpecker, Hairy Woodpecker, Downy Woodpecker, (American Three-toed Woodpecker), Eastern Kingbird, Eastern Phoebe, Crested Flycatcher, Traill's Flycatcher, Least Flycatcher, Olive-sided Flycatcher, Wood Pewee, Tree Swallow, Bank Swallow, (Cliff Swallow),
Purple Martin, Canada Jay, Blue Jay, (Raven), Crow, Black-capped Chicadee, Hudsonian Chickadee, Red-breasted Nuthatch, House Wren, Catbird, Brown Thrasher, Robin, (Hermit Thrush), Olive-backed Thrush, Veery, Ruby-crowned Kinglet, Cedar Waxwing, Yellow-throated Vireo, Blue-headed Vireo, Redeycu Vireo, Philadelphia Vireo, Warbling Vireo, Black and White Warbler, Tennessee Warbler, Nashville Warbler, Yellow Warbler, Myrtle Warbler, Black-throated Green Warbler, Blackburnian Warbler, (Chestnut-sided Warbler), Black-poll Warbler, Palm Warbler, Ovenbird, Water-thrush, Mourning Warbler, Canada Warbler, Yellow-throat, Redstart, House Sparrow, Yellow-headed Blackbird, Redwinged Blackbird, Baltimore Oriole, Bronzed Grackle, Rose-breasted Grosbeak, Purple Finch, (Pine Siskin), Goldfinch, Red Crossbill, Slate-coloured Junco, Chipping Sparrow, Whitethroated Sparrow, Swamp Sparrow, Song Sparrow.

Apart from the names in brackets, all species listed are assumed, on the basis of nest records or of sight records in numbers and at a time of year which would suggest nesting, to be breeding birds. The YELLOWTHROATED VIREO is an especially interesting record as the specimen taken at Madge Lake June 4, 1951, by Fred Lahrman is the first provincial record for the species (Blue Jay, Vol. XI, No. 1, p. 19).

\section{SUMMER MEETING AT MADGE LAKE}

An enjoyable and educational two-day program has been arranged for June 9 and 10. Come early and get in at least one full day of birding, botanizing and photography. Boat trips leave at 8:00 a.m. There will be a program of films Saturday evening. Phone Johnny Herron, Resort manager, Duck Mountain Provincial Park, Kamsack, Sask., if you want sleeping accommodation at the lake. 
Madge Lake Photos by F. Lahrman

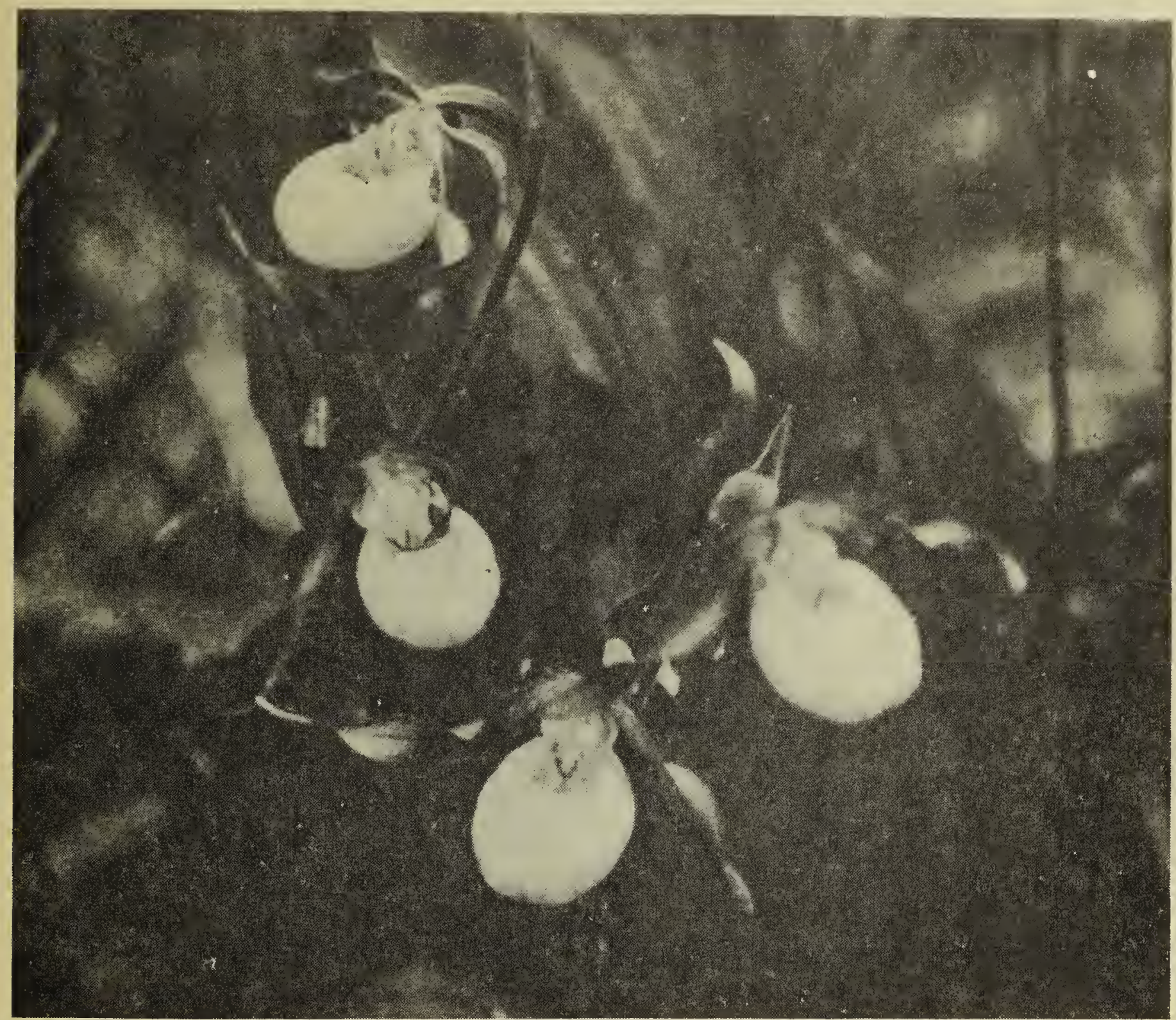

Yellow Lady's Slipper

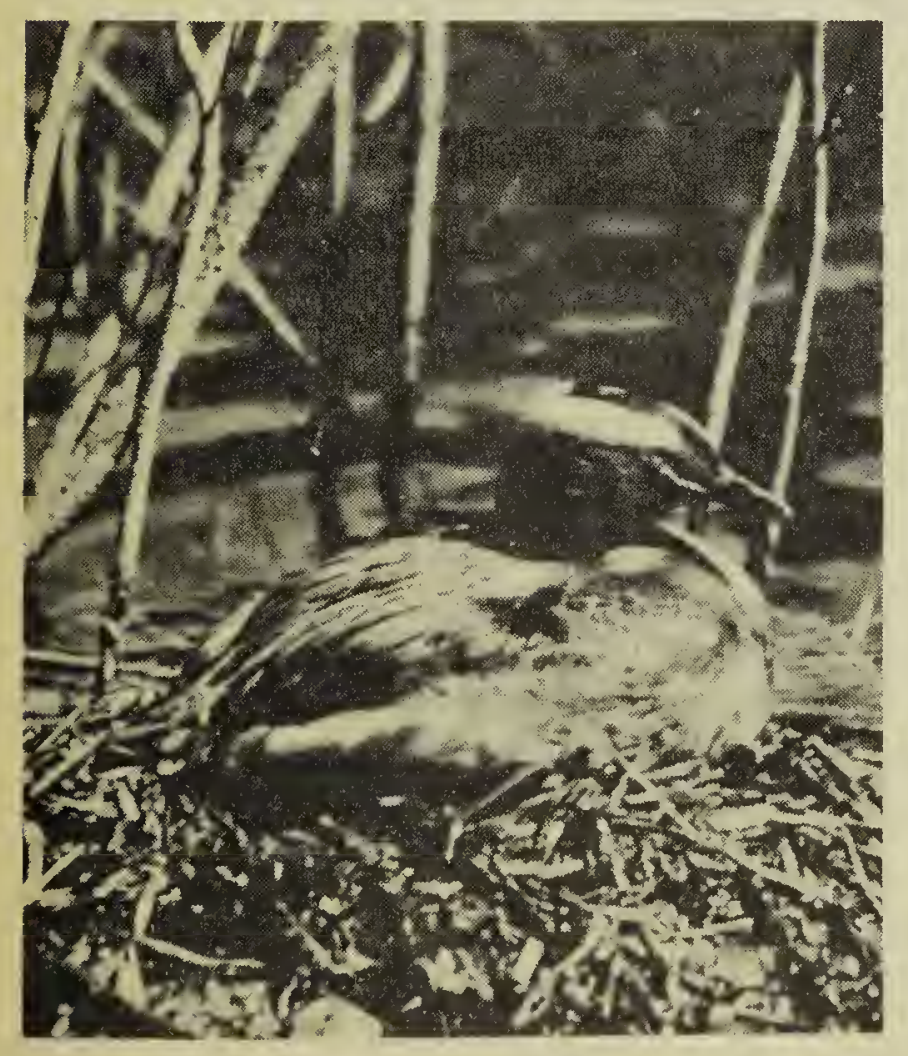

Horned Grebe

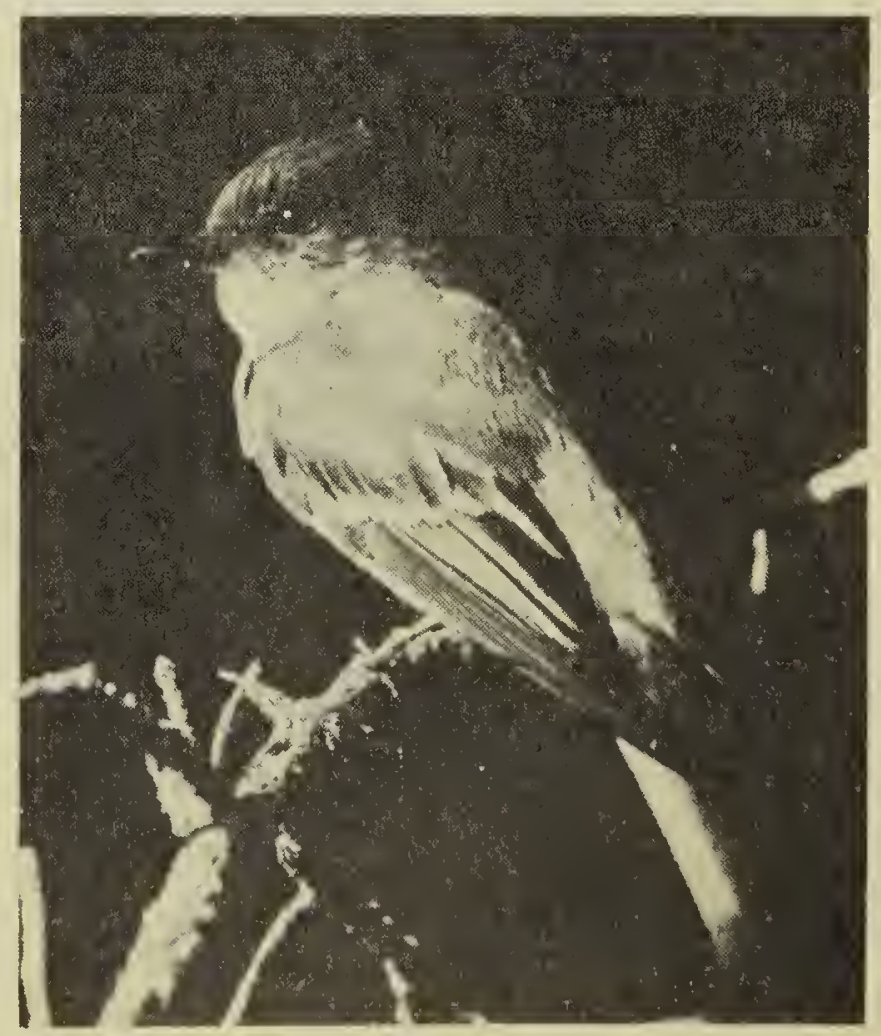

Eastern Phoebe 